\author{
T. Dolidze \\ Batumi State Maritime Academy, Georgia \\ (Corresponding author's E-mail: tm.dolidze@bsma.edu.ge)
}

\title{
Challenges of ESP Education in Georgia during COVID1-19 Pandemic
}

\begin{abstract}
This paper aims at highlighting the general challenges faced recently during the COVID-19 pandemic in the field of English for Specific Purposes (ESP) education in Georgia. For better acknowledging and understanding of the role of the ESP teachers the paper provides definition of the terms, their origin, division into different groups, analysis of various types of ESP. The work serves as an attempt to show the importance and challenges of ESP teachers during its teaching process and at the same time to highlight a growing demand for ESP at the global employment market, being a main medium for professional and business communication across the world. It also aims at demonstrateing the deficiency in ESP area which can result in barriers for graduates' personal and professional development, in particular during the times of a pandemic.
\end{abstract}

Keywords: ESP, EFL, education, challenges, curriculum development, professional, vocational, communication, skills.

\section{Introduction}

Teaching of English for Specific Purposes (ESP) has become a rather popular trend in EFL field, which is considered a separate activity within it. ESP mostly focuses learners' attention on the language and communication requirements in a specific vocational field. It is believed that ESP teachers have elaborated their own teaching methodology and have categorized it as a separate branch of applied linguistics with its characteristics. Therefore, ESP even if separated from the well-established standards of ELT, has always attempted to effectively communicate in the assignments given according to their field of study and work-related surrounding. The main impact of ELT is based on practical results, though the theory of ESP can be designed on its specific nature that it is oriented on needs-related teaching.

Foreign language teachers for specific purposes have a lot in common with teachers of general foreign language. For both it is necessary to consider linguistic development and teaching theories, to have insights in contemporary ideas regarding their own position and role as well as the position and role of foreign language learners in education and to face new technologies offered as an aid to improve their methodology. The needs to understand the requirements of other professions and willingness to adapt to these requirements differentiate the foreign language teachers for specific purposes and their colleagues teaching general foreign language. ESP teaching presumes teaching of English as a foreign language regarding specific profession, subject or purpose.

\section{Literature Review}

Definitions of ESP date back to 60s of the XX century, when it became evident that General English Courses failed to meet the learners, and consequentially, employers' needs. As English was the lingua franca in the field of business, media, technology, science, medicine education and research, the growing demand for ESP was observed in the countries where EFL served the instrumental and supplementary aims [1].

As it is generally recognized, ESP refers to teaching and studying English for a particular career (e.g. engineering, legal, medical) or for Business in General (Business English). In case of ESP learning there is always a specific cause for learning. Therefore, some authors define ESP as "Goal Oriented Language Learning" [2]. From this viewpoint, the purpose of learning English became the starting point for the emerging field.

According to Hutchinson and Water's definition the fact that "learners know specifically why they are learning a language" [3] is indeed mutually beneficial for the teachers and learners and makes it more feasible and realistic for both of them to achieve the goals set. Though, the learner and the method of learning play a crucial role in the above-mentioned process.

Definitions of ESP in the literature are relatively late in time if we assume that ESP began in the 1960s. Hutchinson and Waters define ESP as an approach rather than a product, meaning that ESP does not involve 
a particular kind of language, teaching material or methodology. The basic question of ESP is why does this learner need to learn a foreign language? The purpose of learning English became the core [3].

Definition of ESP makes a distinction between 1) absolute characteristics (language teaching is designed to meet specified needs of the learner; related in content to particular disciplines, occupation and activities; centered on the language appropriate to those activities in syntax, text, discourse, semantics, etc., and analysis of the discourse; designed in contrast with General English) and 2) two variable characteristics (ESP may be restricted to the language skills to be learned, e.g. reading; and not taught according to any previously intended methodology) [4].

According to Robinson's definition ESP is based on two criteria: 1) ESP is normally 'goal-directed', and 2) ESP courses develop from a needs analysis, which aims to specify what exactly it is that students have to do through the medium of English. A number of characteristics which explain that ESP courses are generally constrained by a limited time period in which their objectives have to be achieved and are taught to adults in homogenous classes in terms of the work or specialist studies that the students are involved in. Nor does it consist of a particular type of teaching material. Understood properly, it is an approach to language learning, which is based on learner need [5].

A very interesting and constructive definition of the term ESP is developed by Pr. Lorenzo Fiorito, according him to ESP is a combination of the subject matter and EFL teaching andis, being highly motivating as the students are able to use obtained knowledge in their main activity field, be it business management, accountancy, advocacy, legal writing, tourism, medicine, etc. Therefore, the ability to make use of the lexis and structures in a meaningful context reinforces their acquired knowledge and boosts their motivation. The term specific in the ESP refers directly to the specific purpose of learning English and the students approach learning English through the field that is familiar and relevant to them, i.e., they can use what have they learned outside the classroom. Experienced EFL teachers can use their background in language teaching, recognizing the ways in which their teaching skills can be adapted for ESP teaching. Moreover, ESP teachers are in need of regular contact with field specialists to develop proper lessons in the subject matter being taught. To sum up, ESP teacher must play different role of organizing the courses, setting learning objectives, establishing positive learning environment in the classroom and evaluating students' progress [6].

According to the same author, ESP "assesses needs and integrates motivation, subject matter and content for the teaching of relevant skills" [6]. For this purpose, ESP is actively taught in HEIs all over the world, including Georgia in order to prepare the future specialists in various activity fields and it is supported by the international organizations and employers organizing specializing courses for their workforce to increase their proficiency level of English and at the same time competence in various professional areas.

Therefore, the challenges in the field of ESP education has become rather noticeable since early days of its integration into the academic calendar of HEIs in Georgia, including Batumi State Maritime Academy (www.bsma.ge); Batumi State University (www.bsu.ge) and Grigol Robakidze University (www.gruni.edu.ge), where the author have been delivering ESP subjects since 2005, e.g. Business English (Mandatory Module), Business Communications in English (Optional Module taught in the VII Semester-15 Theory +30 Practice), Legal English I and II (also Optional Subject) and at the same time a very popular subject of discussion during local and international scientific and practical EFL, among the members of SIG (special interest groups) of IATEFL and other EFL associations, gathering ESP teachers and bringing stills existing gaps and as well as emerging problems in the field on board and seeking achievable solutions for more effective and specific aims-oriented ESP Teaching.

In comparison with the ESL learning contexts, the ESP students' motivational levels should thus be enhanced by their knowledge of the subject matter, their interest in the field fuelling their active participation in English classes. As Fiorito states, ESP "assesses needs and integrates motivation, subject matter and content for the teaching of relevant skills" [1].

\section{Main Text}

As mentioned above, since the 60s teaching ESP has always been a subject of discussion in terms of the course design, i.e., how to design the syllabi for ESP based on theoretical or more practical topics, meeting the job-oriented needs of the students and mostl importanty supplying them with up-to-date and recent development in the particular areas, be it Business English, Business Communications or Legal English, as all the above-listed subjects require individual approach, plus development of the materials and authentic resources, i.e., articles, recent case law and publications in order to make the delivered subjects useful and practical at their employment sites. 
Hence, to cover all the above fields listed in the area of ESP education and its effective organization course planning plays a crucial role, which must be based on answering the following questions: why do students need to learn? Who are the stakeholders? Where is it held? What do they need to learn? How can it be achieved?

Recently, the announcing of COVID-19 outbreak from March 12, 2020 by WHO as a pandemic have resulted in taking urgent actions and steps not only in the areas of primary vital importance but also in the life of academia; revision and adaptation of ESP courses meeting the needs of online teaching as well as enforcing the instructors and learners to fully switch to fully ICT-based learning environment became absolutely necessary. In a globally shared new reality and under mandatory circumstances, ESP instructors of Georgia started to share and exchange their approaches to most effective online teaching platforms, programs (zoom, cisco webex, social media platforms, etc.) and did their best in order to timely respond to the challenge of all the mankind, i.e., succeeding in mandatory integration of technology in their ESP learning process within the shortest ever terms.

As for the ESP education, where technology has always been present, especially since 60 s, earlier than in any other academic field, integration of technology has been particularly present for demonstrating authentic materials, e.g. news, live recordings, TED talks and videos, being a usual language practice in progressive and constant development-oriented ESP teaching countries, among them in Georgia, where technology has been widely applied and integrated into ESP classroom not only at higher educational institutions but at secondary and primary educational institutions as well while teaching EFL.

A great number of teacher training programs organized by international (e.d. British Council, International House, IATEFL, etc.) and local (ETAG - English Language Teachers' Association of Georgia), including Specific Interest Groups of BE teachers (SIG BE), international scientific and practical conferences, forums, workshops held virtually and on site so far have greatly contributed to introducing and practicing internationally recognized and approbated standards of ESP teaching/learning through effective usage of technologies in a real life situations and daily encounters with our target audience at HEI in Georgia. Though, some teacher training programs seldom offered training on ESP education through usage of ICT, which resulted in failure of spur of the moment transition to online teaching and once again highlighted the necessity for training teachers, including ESP teachers in order to effectively incorporate ICT into their in real classroom and make it as diverse and versatile as possible.

At the background of the above-mentioned problems, based on the observations of the delivered online classes as well as observed recent practice in Georgia, we came to the conclusion that ESP teachers faced a number of challenges as incorporating the ICT proved to be extremely labor-intensive. It was difficult to select the best and most applicable software program for locating authentic materials when only allowed to use zoom platform. As the attendance of all the students is not absolutely guaranteed the teachers need to be sure that all learners have access to instructional materials before submission of the assignment and in this case we need to simply upload authentic materials on the online platforms and get an immediate classroom feedback and understanding from the ones not attending the online meeting, which turned into a rather big problem for the instructors while assessing submitted assignments without having direct contact with the students, as sometimes absolutely well-performed assignments are submitted by the students who hadn 't attend online classes.

Therefore, in this particular situation integration of authentic materials (which cannot be found in the course book) being one of the appealing ways of teaching ESP proved to be a rather challenging for the instructors and the students. While there are students who do not accept authentic materials and media as a learning source and often reject TV Comedy, standup comedy extracts and games labelling them as not major (rather supplementary and optional) learning materials failing to meet their needs and standards, as they simply view learning as a serious process rather than entertainment.

As it was also experienced within this short period, there is a number of teachers who are absolutely devoid of hands-on experience in application of online platforms (ones not having ever attended/presented in online training, seminar, webinar) even among ESP community. This oversight is a topic requesting a separate round-table discussion and highlighting as a serious issue in ESP sphere of Georgia. Therefore, the teachers facing difficulties in applying multimedia technology, i.e., zoom, google drive, whiteboards, break out rooms, etc. were supported by more experienced colleagues and team leaders in mastering and at least moderately effective mandatory application of technology in EFL/ESP classroom, which is mostly devoted to practical classes and students are usually expected in class interaction and on-site work. Though, abovementioned disadvantage very rapidly made so far inexperienced teachers to apply support of the moment act 
and implement new practices in online classes already, which was under ratehr sgtressful and extremely tense environment.

Also, instantaneous transition to ICT based learning in ESP as well as all delivered classes in all HEI of tertiary and secondary educational level of Georgia and globally, turned out to be rather costly and even unaffordable for some teachers and students as well, especially ones living in remote rural areas with almost no or poor access to Internet and ICT technologies, i.e., laptops, PC or Ipads. Often they had to use their mobile phones, which can be quite ineffective and technically inefficient for performing a great number of online tasks. Thus, HEIs of Georgia were forced to take unforeseen costs for the purposes of investment of money for acquisition of necessary software programs for ICT learning, e.g. licensed zoom.

Thus, as we can see, from today's perspectives mandatory application of technology in ESP Classroom at the level of education of Georgia, in particular of the example of delivering BE classes among the Students of Business and Management Faculty of Batumi State Maritime despite significant joint and integrated efforts undertaken by the Management of HEI, ICT team, Quality Assurance Service and Academic and Invited Personnel became feasible and achievable within incredibly shortest term under distinguish new and stressful isolated conditions and state resulting from COVID-19 situation. Though, under regular and nonstop communication and contact with all the stakeholders and the learners themselves, ESP and in general all classes were fully moved to ICT-based learning and assessment phase.

\section{Conclusion}

Based on the recent developments in ESP education we can conclude that if compared to General English ESP Education has been characterized by more challenges focusing on learners' specific needs, making a significant accent on mastering the language in context and students' intention to acquire vocational skills and specific job-related functions. ESP education requires regular testing from the side of the teachers being responsible for it. In order to successfully overcome the challenges faced in the ESP education joint efforts were taken from all involved stakeholders, i.e. teachers and students during the pandemic. It indeed required joint efforts by teachers and students, with a key focus on the needs and constraints of the latter, with certain learning autonomy, which was rather difficult to achieve especially when delivering ESP classes online, without having direct exposure to the class. This to certain extent diminishes the role of the teacher and causes them to fail to reach the goals and objectives set for particular ESP Class.

Furthermore, the above-mentioned observations and findings in ESP education showed us that the challenges and problems identified during COVID-19 pandemic and still existing in ESP education in Georgia in the above listed HEIs are in no way different from universally recognized problems and challenges found all over the world, with ESP teachers' more complex role and responsibility compared to General English Teachers, as they not only represent materials providers, they also act as syllabi designers, collaborators with field specialists, researcher and finally, overall evaluators of the course and the learners themselves. This once again assures that the above-discussed challenges existing in ESP Education cannot be settled without continuous cooperation of the ESP teachers, their role and contribution is immense and they have to be aware of the course objectives, have a proper understanding of the course content and of course, be adaptable to ESP learners' needs and constraints. It is a challenge itself to find professional ESP teachers, the only to create and expand a local and international network of professional and more experienced ESP teachers, equipped with necessary competence, resources, innovations and field requirements, flexible and able to switch from one professional field another withouthaving obligation to spend much time on entering the ESP classroom. Hence, ESP teachers need to bring necessary tools, frames and principles of the course design in order to use them in new materials, bearing in mind that ESP teachers are not specialized in the field, indeed they are specialized in teaching English. Only, after following and considering all these necessary steps and measures we can move to successful settlement of the problems and challenges faced in ESP education in Georgia and internationally through making our voices heard.

\section{References}

1 Dudley-Evans, T., \& St John, M. (1998). Developments in ESP: A multi-disciplinary approach. Cambridge: CUP.

2 Robinson, P. (1991).ESP Today: a Practitioner's Guide. Hemel Hempstead: Prentice Hall International.

3 Gatehouse, K. (2001). Key issues in English for Specific Purposes: (ESP) Curriculum development. TESL Journal Vol. VII, No. 10, October 2001. iteslj.org. Retrieved from http://www.iteslj.org/Articles/Gatehouse-ESP.html

4 Hutchinson, T., \& Waters, A. (1987).English for Specific Purposes: a Learning-centered Approach, Cambridge: CUP. 
5 Robinson, P. (1991).ESP Today: a Practitioner's Guide. Hemel Hempstead: Prentice Hall International.

6 Fiorito, L. (2005). How is English for Specific Purposes (ESP) different from English asa Second Language (ESL), also known as general English? usingenglish.com. Retrieved from www.usingenglish.com

\title{
Тамари Долидзе
}

\section{Грузиядағы COVID-19 пандемиясы кезінде арнайы мақсаттағы ағылшын тілін оқыту мәселелері}

\begin{abstract}
Мақала Грузияда COVID-19 пандемиясы кезінде арнайы мақсаттар үшін ағылшын тілін оқытуда пайда болған мәселелерді жариялауға бағытталған. Арнайы мақсаттағы ағылшын тілі мұғалімдерінің рөлін жақсы түсіну үшін мақалада терминдердің анықтамасы, олардың шығу тегі, әртүрлі топтарға бөлінуі, арнайы мақсаттар үшін ағылшын тілін оқытудың түрлері де талданған. Аталған жұмыста оқу процесі кезінде мұғалімдердің маңыздылығы мен мәселелерін көрсетуге, сонымен қоса бүкіл әлемдегі кәсіби және іскерлік қарым-қатынастың негізгі құралы болып табылатын, әлемдік еңбек нарығындағы арнайы мақсаттағы ағылшын тілін оқытуға сұраныстың артып келе жатқаны туралы айтылған. Сонымен қатар, мақала арнайы мақсаттар үшін ағылшын тілі саласындағы пандемия кезінде түлектердің жеке және кәсіби дамуына кедергі келтіруі мүмкін мәселелерді көрсетуге бағытталған.
\end{abstract}

Кілm сөздер: арнайы мақсаттар үшін ағылшын тілі, ағылшын тілі, білім беру, мәселелер, оқу бағдарламаларын әзірлеу, кәсіп, кәсіби коммуникация, дағдылар, іскерліктер.

\section{Тамари Долидзе}

\section{Проблемы обучения английскому языку для специальных целей в Грузии во время пандемии COVID-19}

\begin{abstract}
Статья направлена на освещение проблем в области обучения английскому языку для специальных целей, с которыми столкнулись во время пандемии COVID-19 в Грузии. Для лучшего понимания роли учителей английского языка для специальных целей в статье даны определения терминов, их происхождение, деление на разные группы, проанализированы различные виды английского языка для специальных целей. Данная работа - попытка показать важность и проблемы учителей английского языка для специальных целей во время учебного процесса и в то же время подчеркнуть растущий спрос на английский язык для специальных целей на мировом рынке труда, являющемся основным средством профессионального и делового общения во всем мире. Кроме того, статья направлена на демонстрацию недостатков в области преподавания английского языка для специальных целей, которые могут создавать препятствия для личного и профессионального роста выпускников, особенно во время пандемии.
\end{abstract}

Ключевые слова: английский язык для специальных целей, иностранный язык, образование, проблемы, разработка учебных программ, квалификация, профессиональная коммуникация, навыки и умения. 